\title{
A „Főmondatok előhívója” - Emlékezés Ágoston Magdolnára
}

Elmentem ma is futni a Bükkbe. Azon az úton, ahova egyszer Magdát is elvittem kirándulni. Csodálatos volt minden, az erdő már nagyon él. A zöldnek, a klorofillbőség miatt, ilyenkor közelítőleg 40 árnyalatát tudjuk megkülönböztetni. Mikor hazaértem, heurisztikus élmény kerített hatalmába: visszafelé futottam az $5 \mathrm{~km}$-es futókört! Utoljára akkor mentem ezen az erdei úton fordítva, vagyis visszafelé, mikor Magdával voltam itt. Ez most ócska dramaturgiai fogásnak tünhet, de nem az! Vannak mágikus és metafizikai hatalmak.

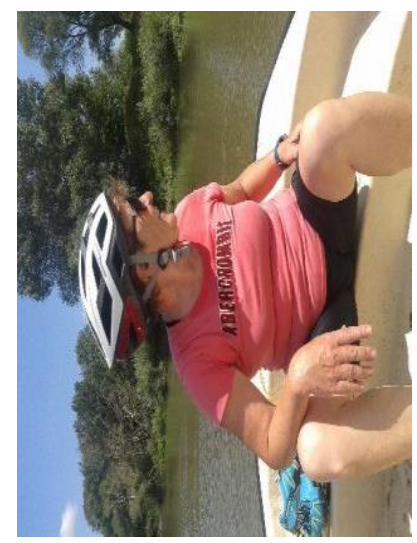

Futni valahogy mindig az óramutató járásával ellentétes irányba

futunk. Ez ösztönszerü. Ma, az óramutató járásával megegyező irányba, az érzékelés szintjén mégis visszafelé futottam: a jelenből a múltba. Furcsa ez a retrospekció! Emlékszem, hogy folyamatosan felfelé nézett. Csodálta az erdőt. Tudatosan mély, nagy levegőket vett, s nagyokat lépett. Feltöltődni jött. Örültem, hogy örömöt okozok neki.

A tanárom volt.

Legmélyebb együtt töltött pillanatainkban is a tanáromnak láttam. Gyengeségeiben is sziklaszilárd, óriási tudású szakembernek, akinek egy-egy mondata, egy apró megjegyzése is képes volt ezer gondolat megindítására. A kreativitásnak szikrát adott, ő volt a személyes tanulási tér.

Főmondatok előhívója. Így neveztem őt el. Ezt el is mondtam neki, s hogy megértse, definiáltam is Főmondat-filozófiámat:

- A Főmondatok egyszerüek.

- A Főmondatok egyszerre kérdő, kijelentő, felszólító, felkiáltó és óhajtó mondatok.

- Főmondatot senki nem adhat senkinek.

- Főmondatot senki nem vehet el senkitől.

- A Főmondatot meg kell szülni.

- A Főmondat önmagában áll, de születése jogán bármilyen kontextusba beilleszthető.

„Mókuska! Ebből semmit nem értek!” - ez volt a válasz. 
Persze, hogy nem értette. Előhívónak lenni nem egyszerü lakmuszpapír funkció. Nem valamiféle vegyszertiszta tulajdonság birtoklását jelenti. Az előhívás sosem pontos, nem teljes, nem egzakt, nem bizonyos, nem hasznos, azaz nem pozitív a pozitivizmus értelmében. Egyszerüen mindig cselekvésre, elmélyülésre, problémamegoldásra sarkall. A kimondhatóság, s az elgondolhatóság határai közti fesztültséget elmosó profizmus.

„Taníts valamire!” - ez az én Főmondatom, amit ő hívott elő belőlem.

Mindig ezzel nyaggattam, vágytam arra, hogy tanítson. Skype-on, kávézás közben, biciklitúrán, tanulmányíráskor, ha bejött meghallgatni az órámat, amikor lektorálta az írásaimat és hallgatásaink közben is.

„Mire tanítsalak, arany csillagja?” - kérdezte egyszer.

„Mindegy. Taníts valamire” - adtam meg a pontos választ. Mert ez volt a pontos válasz, s ezt már akkor is tudtam.

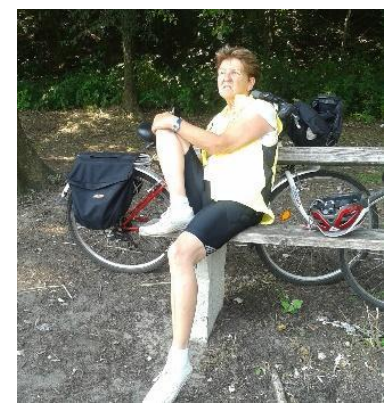

Mellette ugyanis nem volt megállás. Folytonos létmegértésben

kerekeztünk. Vele nem lehetett csak úgy következmények nélkül beszélgetni, mint futólag a folyosón, vagy reggelizés közben.

Egyébként ténylegesen is mindig rohant. Szakadatlanul millió dolga volt és ezerfelé tudott szakadni, de mégis mindig jelen volt. Jelenléte a hétköznapi szituációkban épp úgy, mint a kihívást jelentő élethelyzetekben mély volt és teljes.

Ezzel, nemcsak engem tüntetett ki, tudom. Talán pont ez a tulajdonsága tette vonatkoztatási ponttá a szociális szakma koordináta-rendszerében is.

Ez a sok zöld, ma nagyon tetszett neki...

A megemlékezést készitette Szibrik Gabriella. 